\title{
A térségi boom gazdasági és társadalmi következményei
}

\section{The socio-economic consequences of regional booms}

\author{
LUX GÁBOR
}

KULCSSZAVAK: boom, konjunktúraciklusok, területi multiplikátor, beruházások, ipar

\begin{abstract}
ABSZTRAKT: A tanulmány a jelentős külső erőforrásokat, különösen munkaerőł bevonó projektek által érintett térségek fejlődését vizsgálja. Az ásványkincsek és energiahordozók kitermelése, megaesemények és ipari nagyberuházások keltette boomok konjunktúraciklusai megbontják a térségi gazdaság egyensúlyát; többletkereslete† és új növekedést, de hiányjelenségeket, kifulladásukkal pedig kiürülési folyamatokat és térségi depressziót idézhetnek elő. A tanulmány ismerteti a boomok típusait és lehetséges gazdasági következményeit, az általuk kiváltott multiplikátor- és tartós szerkezetátalakulási hatásokat, figyelmet fordít a közszolgáltatások és az infrastruktúra keresleti és kínálati oldala közötti egyensúly felborulására, és a káros társadalmi mellékhatások kezelésének alternativáira. Végül következtetéseket fogalmaz meg a Magyarországon zajló vagy tervezett beruházási projektek speciális problémáira, a bennük rejlő növekedési lehetőségekre és kockázatokra.
\end{abstract}

KEYWORDS: boom, business cycles, regional multiplier, investments, industry

ABSTRACT: This paper examines the development of regions where large projects mobilising significant resources, especially labour, take place. Booms originating in the extractive industry, around mega-events and large-scale industrial investments break the equilibrium of regional economies, bringing with them additional demand and new growth opportunities, but also symptoms of shortage, and when they unwind, the possibility of regional erosion and depression. In peripheral areas characterised by a low intensity of economic activity, the effects of booms are especially notable because they involve large quantities of exogenous capital and labour.

The resulting boom effects involve a range of components which may be positive (primary, indirect, inter-industrial and other induced effects) as well as negative (displacement, re-spending and substitution effects), which all combine to generate a complex boom effect. The core issue of boom economies is the ultimate outcome of regional stabilisation after the boom and bust forces have run their course: a return to normality; regional depression; or a new development trajectory. Regional multipliers may generate short-term gain, but also contribute to lasting restructuring processes; the local entrepreneurial milieu might use the income injection of the boom to break out of pathdependency and enlarge the scope into a learning-curve and upgrading process.

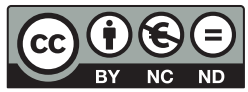


A relevant aspect of booms is the mismatch between the capacity of local infrastructure and services and increasing demand: this generates shortages and crowding-out under the boom, and leaves over-capacities in the unwinding of the bust phase. These disruptions may be addressed by approaches of anticipative and participative planning, employing a range of impact-mitigating instruments, although these require a sufficient level of local decision-making capacity.

The specific problems of large-scale investment projects underway or being discussed in Hungarian regions require further analysis. In the preparatory phase, environmental impact assessment is now common practice, but the broader socioeconomic implications are not being considered in planning. In between the production-centric investor and the public sector, there is a missing link in either impact mitigation or a regulated integration of beneficial boom effects into local development; moreover, we do not even know the true extent of the socioeconomic changes taking place. This is all the more important since in boom areas, there is a hazard of advantageous effects being rerouted towards more efficient external competitors instead of locally embedded actors, leaving the local economy unaffected by the boom, but left to bear the socio-economic costs of both the boom and the bust. It is postulated that a more thorough investigation of concrete investment projects, and a re-evaluation of local development policy should take place in Hungary.

\section{A térségi boom fogalma és problémái}

A koncentrált, nagy volumenü beruházások erőforrás-szükséglete jelentős fizikai mozgásokkal jár (anyagok és személyek mozgása), a beruházási tevékenység időtartamára átformálja az építkezés tágabb környezetét. Az általános logisztikai problémák mellett a külső munkaerő tömeges bevonása ideiglenes, középvárosi léptékben számottevő népességnövekedéshez vezet, ami lokálisan az erőforrásfelhasználás és az áruk, szolgáltatások, valamint infrastruktúra iránti kereslet jelentős növekedését eredményezi. A rövid és hosszú gazdasági ciklusokon túl egyszeri vagy legalábbis ritkán bekövetkező, rövid lefutású konjunktúraciklus zajlik le, amely az előbbiektől függetlenül, de velük összeadódva fejti ki hatásait. Ebben a tanulmányban boomon az egész konjunktúraciklust értem, ideszámítva annak felfutó (konjunkturális) és hanyatló (dekonjunkturális) szakaszát is. Nem tekintem viszont a boom részének a térségi gazdasági és társadalmi szerkezet hosszú távú átalakulását; a strukturális hatásokat a boom következményei között tárgyalom.

A keresletteremtésen túl a beruházási projekt további hatásokkal is jár: megterheli az állandó népességszámhoz igazodó kapacitásokkal rendelkező infrastruktúrát, intézményrendszert és - még ha a projektmenedzsment alvállalkozók bevonásával maga biztosítja is szolgáltatások egy részét - leköti annak kapacitásait.

A konjunktúraciklus egyszerre jelent megoldandó problémákat, feszültségforrásokat és növekedési lehetőségeket. A következmények nemcsak ipartelepítésnél, hanem más nagy építési projekteknél (pl. olimpiák, világbajnokságok, jelentős kulturális események) is bekövetkeznek; sőt, nem csupán egyes 
nagyberuházások, hanem a beruházási tevékenység több forrásból táplálkozó radikális emelkedése is kiválthatja őket.

Az építési boom mellett annak lecsengése is hatással van a térségi gazdaságra, amely sokkhatásként jelentkezhet, és az ideiglenes túlfütöttség generálta kereslet megszűnésével az új kapacitások kihasználatlanságához, vállalkozások tömeges csődjéhez („,bust”) vezethet, kedvezőtlen esetben depressziós jelenségek alakulhatnak ki. További dilemmát jelent az építkezés során létrejött kapacitások alternatív hasznosításának vagy leépítésének kérdése, amely kedvezőtlen esetben a közszféra terheinek előnyök nélküli tartós növekedéséhez, kedvező esetben új, fejlesztésbe vonható erőforrások megszerzéséhez vezet.

Ebben a tanulmányban a közgazdaságtan, szociológia és regionális tudomány eredményeit használom fel a boom hatásainak ismertetésére, majd következtetéseket fogalmazok meg a Magyarországon zajló vagy tervezett ipari nagyberuházások lehetséges térségi következményeire. Különös jelentőséget adnak a kérdések feltevésének azok a beruházási döntések, amelyek a feldolgozóiparban (Mercedes Kecskemét, Audi - Győr), az energetikában (a Paksi Atomerőmű bővítésére irányuló tervek) és más iparágakban vezetnek új kapacitások létrehozásához és régiek bővítéséhez. Bár a beruházások elsődleges eredménye maga a felépített üzem, a beruházási folyamat önmagában növekedési lehetőségeket és - területi léptékben, a lokalitás és a regionalitás kontextusában értelmezhető - problémákat generál. Ezek a „mellékhatások” a végeredményhez mérten csekélyek, de egy középváros és környezete számára jelentős forrásokat, növekedési impulzusokat hordozhatnak.

A hivatkozott szakirodalom elsősorban a boom iránt legjobban érdeklődő angolszász - ezen belül észak-amerikai - kutatások eredményeire támaszkodik. Az első jelentős empirikus vizsgálatok az 1970-es évek második felétől az 1980-as évek végéig terjedő, az energiatermelő projektek számának megsokszorozódását hozó időszakban zajlottak. A következő évtizedekben a téma más területeken, így a feldolgozóipari működőtőke-beruházásoknál és a nagyvárosokban megvalósított építési projektek hatásvizsgálatainál is megjelent, illetve további, gyakran ex post vizsgálatokat végeztek a már kutatott boomtérségekben.

Magyarországon az államszocializmus időszakában, az egyoldalúan termeléscentrikus, vállalati szempontokra összpontosító fejlesztéspolitika hatásainak utólagos elemzésében és a válaszul született korrekciós kísérletek kapcsán vetült elsőként figyelem a boomjelenségek hosszú távú következményeire, elsősorban a településpolitika és egyes részterületei (infrastrukturális, intézményi és lakásellátottság, városi szolgáltatások - a boom mellékhatásaként elöidézett hiányjelenségek), valamint a területfejlesztés szemszögéből. A jelenség területi szemléletű értékelésére elsőként az 1960-as évek második felében született jelentős munkákban (Kóródi, Márton 1968, Kóródi, Kőszegfalvi 1971), majd az 1970-es években föként a Területi Statisztika hasábjain, elsősorban Kőszegfalvi György tanulmányai között, illetve monográfiájában (Kőszegfalvi 1978) találunk színvonalas példákat. ${ }^{1}$ Az évtized végétől a téma iránti érdeklődés elcsitult, a kutatói érdeklődés más kérdések, például a leszakadó térségek problémái felé fordult. 
Ezek a kutatások a maitól merőben eltérő gazdasági, társadalmi és politikai feltételrendszerben születtek, egyes módszertani megállapításaik mellett mégis szolgálnak egy ma is különleges aktualitású tanulsággal. Az ipari nagyberuházások előkészítése során a körültekintően megalapozott vállalati telephelyválasztási döntések és a tervezési fázisba környezeti szempontokat bevonó stratégiai környezeti vizsgálatok (Varjú 2009) mellett nem kerül sor a térséget érő járulékos társadalmi és gazdasági hatások felbecslésére. Vagyis a ma is termeléscentrikus beruházó és a környezeti kontrollt elvégző közszféra szűk területekre korlátozódó vizsgálatait leszámítva ma sem kapunk pontos képet arról, hogy egy beruházási folyamat vagy megvalósult beruházás milyen pozitív és negatív térségi hatásokat generál majd. A közpolitika, ha kezd is valamit a kialakuló helyzettel, ezt kész tényekre reagálva, ex post végzi el ahelyett, hogy anticipálná és a kialakuló boom előtt mérsékelné a kibontakozó problémákat, vagy saját fejlesztéspolitikai döntéseibe illesztené és kihasználná a nagyberuházások pozitív externáliáit. ${ }^{2}$ Az utólagos korrekció, ahogy régen, ma is költségesebb: nagyobb károkat, kihagyott lehetőségeket jelent.

\section{A boom formái}

A boom három fö típusát különböztetjük meg:

- klasszikus kitermelési boom: természeti erőforrások, elsősorban fémek és energiahordozók kitermeléséhez kötődő konjunktúra-időszak;

- nagyrendezvények (megaesemények) boomja: kontinentális vagy globális vonzerejü idegenforgalmi események létesítményberuházásaihoz, valamint az esemény által kiváltott helyi kereslethez kötődő konjunktúra;

- ipari nagyberuházások boomja: két részre oszló, egy beruházási (építési) fázisban konjunkturális, boomjellegü, az azt követő üzemeltetési fázisban pedig a bázisidőszaknál tartósan magasabb gazdasági aktivitást generáló projekt.

Mivel a megaesemények a téli olimpiák kivételével szinte mindig nagyvárosi térségekben zajlanak le, és jellegükből adódóan vonzerejük, a térségbe bevont tőke jellege és működési profilja, valamint a nagyon rövid, koncentrált csúcsidőszak miatt kevésbé alkalmasak a Magyarországon zajló vagy tervezett nagyberuházások számára releváns következtetések megfogalmazására, eredményeikre csak korlátozottan támaszkodom. A kitermelési boom és az ipari beruházások boomja az esetleges eltérések dacára jobb példákat szolgáltat:

- helyszínük gyakran rurális tér alacsony gazdasági aktivitással és aránylag zárt kapcsolatrendszerrel;

- a növekedésbe bevont erőforrások - a munka és a tőke - számottevő része érkezik külső forrásból;

- hasonló szerkezetủ és bérszínvonalú munkaerőt mozgatnak meg;

- hasonló a boom konjunkturális és dekonjunkturális szakaszának lefutása. 


\section{A boom gazdasági következményei}

\section{Konjunkturális hatások}

A boom során gyors ütemű és a térség befogadóképességéhez mérten jelentős népességnövekedés, majd a dekonjunkturális szakaszban szintén gyors kiáramlás megy végbe. Mindkét szakasz gazdasági és szociális problémákat generál, miközben, főleg a konjunktúrában, új üzleti lehetőségeket és tudást is teremt. A konjunktúraciklus kilengése értelemszerüen csekélyebb ott, ahol meglévő létesítmények bővítése zajlik le: ez a körülmény tompít bizonyos hatásokat (pl. nem jár a térségi gazdaság alapvető szerkezeti átalakulásával), de megerősít másokat (pl. a helyben megtalálható szakértelemnek köszönhetően több lehetőség nyílik egyes pozitív hatások kihasználására).

A boom gazdasági hatásai több rétegre bonthatók, és együttesen összetett konjunktúrahatást generálnak (Mentzas, Capros, Samouilidis 1987):

- elsődleges hatások: a fö beruházási célhoz közvetlenül kapcsolódó anyagés munkaerőigény;

- indirekt hatások: a térségi termelési és foglalkoztatási rendszerben végbemenő szerkezeti változások;

- iparágak közötti hatások: a helyi gazdaságban eszközölt beszerzések hatásai;

- indukált hatások: a fenti hatások által generált vásárlóerő-többlet termelést és foglalkoztatást növelő hatása.

A hatások teljes köre azonban kedvezőtlen hatásokat is tartalmazhat:

- kiszoritó hatás: az aktív költségvetési korlátok keresletkorlátozó hatása;

- újraelköltési hatás: a boomágazatban keletkezett extra jövedelmek áremelkedést előidéző hatása a non-tradeable (szolgáltató) szektorban;

- helyettesitési hatás: a túlfütött gazdaságban emelkedő árak bizonyos csoportok körében a fogyasztás visszafogását eredményezhetik.

A boom talán leglényegesebb kérdése, hogy milyen stabilizáció következik be a rövid távú konjunktúra lefutása után, milyen lesz a visszaesés után felálló új egyensúlyi állapot. A boom utáni népesség szinte mindig magasabb, mint azt megelőzően, még akkor is, ha a növekedés kiváltó okai már nem találhatók meg a térségben. A gazdaság „felrázása”, „újrarendezése” ugyanis új kapcsolatokat, új kompetenciákat, a boomtól függetlenül is hosszú távon életképes vállalkozásokat hoz létre, amelyek megtartják a beáramló népesség egy részét - amennyiben a dekonjunktúra nem járt súlyos kiszorító hatással a térségi vállalkozások körében. Így a konjunktúraciklus lefutásának három alapvető formájáról tehetünk említést (1. ábra).

Egyszerű értelmezésben a ciklus felfutó (konjunkturális) és hanyatló (dekonjunkturális) szakasza követi egymást, és ezt, amikor a boom eredeti kiváltó hatása megszünik, a korábbi egyensúlyi állapothoz való visszatérés követi (1. a.). A térségi gazdaságban bekövetkezett változások tisztán ideiglenesek, és sem a 
1. ábra: A boom konjunktúraciklusának formái The main forms of boom-bust cycles
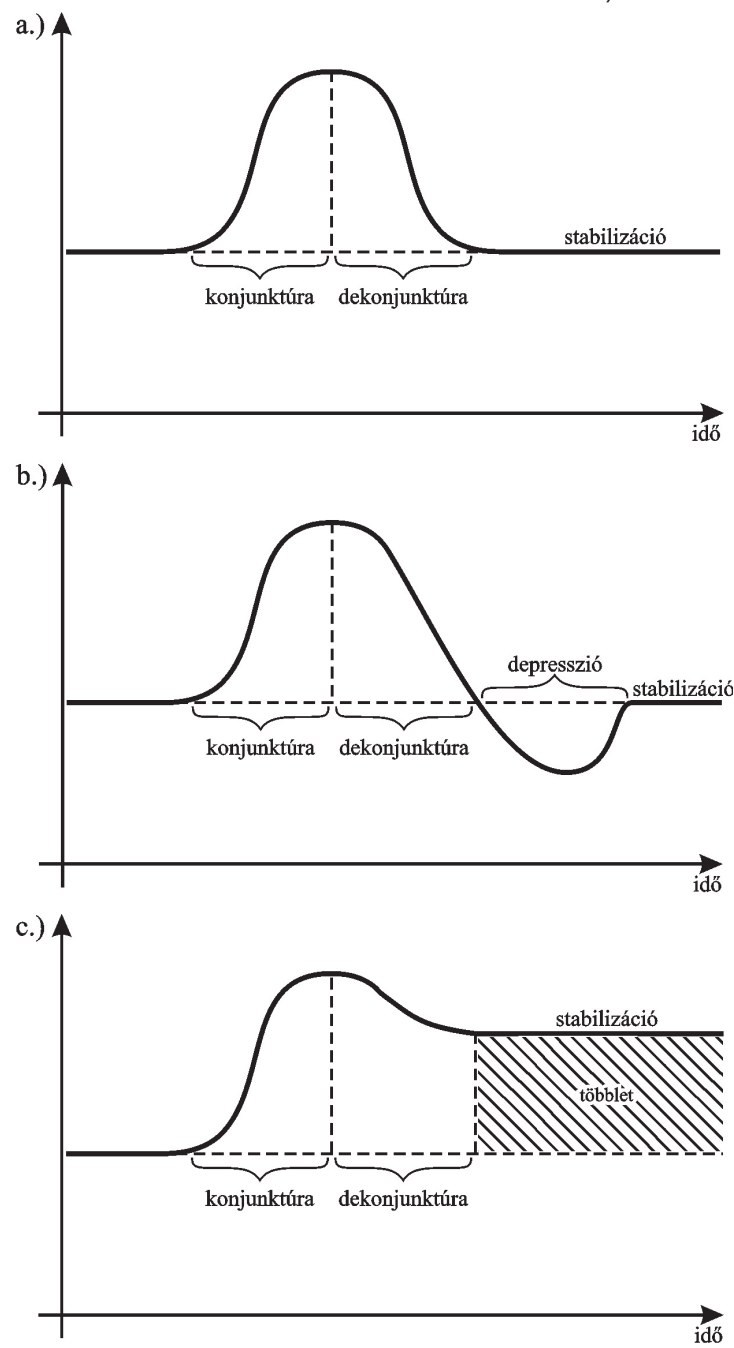

Forrás: A szerző szerkesztése.

pozitív, sem a negatív következmények nem változtatják meg a helyi viszonyokat. Ez tapasztalható azokban a térségekben, ahol

- a boom szinte kizárólag külső források bevonásával valósul meg;

- nem mobilizálja a helyi erőforrásokat (vagy jellegénél fogva, vagy mert nincsenek szignifikáns helyi erőforrások, vagy lennének, de immobilak);

- a keletkezett jövedelmek kiáramlanak a térségből, és az ideiglenesen megjelenő népesség is távozik; 
- olyan termelö-, szolgáltató- vagy infrastrukturális kapacitások sem jönnek létre, amelyek tartós növekedési lehetőségeket kínálnának a térség gazdasága és társadalma számára.

Ilyen például bizonyos autópálya-beruházások térségi hatása: lehetséges, hogy az autópálya által összekötött pontok gazdasági előnyökben részesülnek, de az útvonal által érintett vidéki térségekben a gazdaságfejlesztő hatás nem automatikus - a nagy forgalommal járó építkezés levonulása után a lokalitás gazdasági profilja változatlan marad, vagy elszívó hatás lép fel (egy Magyarországon elvégzett empirikus vizsgálatra lásd Németh 2009).

Az előbbi eset természetesen leegyszerüsített: a dekonjunktúra gyakran nem egy stabil állapotba tér vissza, hanem depressziót, esetleg összeomlást vált ki a térségben (1. b.). Ez a helyzet, ha a boom megszűnésének hatásai kontrollálatlan, öngerjesztő folyamatként erősödő zuhanást eredményeznek. A dekonjunktúra ekkor nemcsak a konjunkturális előnyöket szünteti meg, hanem pusztító hatást gyakorol a társadalom és gazdaság további részére is. A vállalkozások csődhulláma, a finanszírozhatatlanná váló többletkapacitások összeomlása tartósan negatívra fordíthatja a térség növekedési kilátásait; a hátrányos szociális következmények tartósak, és felerősödhetnek az elvándorlási, kiürülési folyamatok - vagyis nincs visszatérés az „idilli” kiinduló helyzetbe. Ez a tendencia akkor is kibontakozhat, ha a konjunktúraperiódus során erős kiszorító hatás érvényesül a térségbe települő tőkeerős külső versenyzők részéről, és a boom előnyeit lefölöző cégstruktúra szereplőinek újbóli kivonulása olyan űrt hagy maga után, amelyet a tartós károkat szenvedett helyi vállalkozói szféra nem képes pótolni. A helyzet általában jóval kevésbé drámai, de a sikertelenül záruló boomok lezárulása általában a boomnál kisebb amplitúdóval rendelkező, rövid távon a kiindulópont alá bukó hullámvölggyel megy végbe, és csak később indul el a térségi gazdaság és társadalom regenerációja. ${ }^{3}$

A boom hatásai legegyszerübben nézve ideiglenesek, de kedvező esetben pozitív örökséget hagynak maguk után (1. c.). Definíció szerint ez a helyzet a termelőüzemek nagyberuházásainál: az építési fázis után a csúcspontnál valamivel alacsonyabban alakul ki az új egyensúly, de a boom térségében a létesítmény teljes életciklusa alatt érvényesül az üzemeltetés foglalkoztatást, tartós népességet és gazdasági aktivitást javító hatása. A többlet nemcsak termelőlétesítmény lehet, hanem bármely tényező, amely a kiindulópontnál nagyobb gazdasági aktivitást tesz lehetővé, és megjelenik a helyi gazdaságfejlesztés rendszerében. ${ }^{4}$ Ilyenek a boom során képződő és új tevékenységekbe áramló tőke; az újonnan létrejött vagy bővülő, a boom után is életképes vállalkozások; a település vagy térség számára hasznos infrastrukturális beruházások és intézmények; a know-how és más, a térségi humán erőforrások színvonalát, szervezettségét és értéktermelő képességét pozitívan befolyásoló tényezők.

Bizonyos esetekben nem csupán magasabb szintü stabilizáció következik be, hanem elvileg ez a bázis egy újabb konjunktúraciklus, esetleg újabb (akár azonos, akár más forrásokból táplálkozó) boom kiindulópontja lehet. Ez min- 
denképpen a legjobb kimenetel, és mint később meglátjuk, a térségi vállalkozói rendszer tanulási folyamataként értelmezhetjük. Egy statikus, merev szerkezetű térségi gazdaságban az egyensúlyi állapot megbomlása nemcsak fenyegetés, hanem lehetőség is: annak a lehetősége, hogy a boom után újrarendeződő gazdaság korábban nem elérhető fejlődési lehetőségeket aknázzon ki.

\section{Multiplikátorhatások}

A közgazdaságtudományban a multiplikátorhatást elsősorban a gazdaság normálállapotára értelmezik, de - bár rövid időintervallumban - az építési, beruházási kiadások is multiplikatív módon érvényesülnek az érintett térségben. A boomtérségek multiplikátorai nagy eltéréseket mutatnak egyes esettanulmányok között; a hatás függ az építési fázis léptékétől és időtartamától, a munkaerő összetételétől, a speciális berendezések és anyagok beszerzésének helyétől (külső és belső sourcing) stb. Armstrong, Darrall, Grove-White (1997) megállapítják, hogy a beruházási multiplikátorok körében csökkenő tendencia mutatható ki, amely az alvállalkozók növekvő bevonása révén elért nagyobb rugalmasság és az építkezési ciklusok rövidülése miatt tapasztalható.

A multiplikátor forrását a munkabéreken és más, helyben realizálódó kiadásokon (anyagok, üzemanyag, megrendelések stb.) keresztül előálló jövedeleminjekció adja. Első körben ez az összesített pénzmennyiség jelenik meg a térségi gazdaságban, majd az elköltött pénz tovagyürüző hatásai szivárognak át újabb és újabb ágazatokba. Feltételezheto", hogy a legnagyobb lokális hatással a munkaerő-állomány költése rendelkezik, ugyanis az alkalmazottak számára a legkevésbé lehetséges a térségen kívüli beszerzés. Ezen a körön belül további különbségeket tehetünk: a teljes jövedeleminjekción belül más fogyasztási viselkedéssel rendelkeznek a családos betelepülők, az egyedülálló betelepülők, az ingázók, a helyi alkalmazottak és mások. Nagyberuházások építési fázisában az első két csoport többletjövedelme képviseli az injekció számottevő részét; a térségen kívülről ingázók esetén a fogyasztás és így a multiplikátor jelentős része máshol érvényesül, míg a helyi alkalmazottak költik el jövedelmük legnagyobb hányadát a térségen belül (Glasson, van Der Wee, Barrett 1988, Armstrong, Darrall, Grove-White 1997). Hozzá kell tenni, hogy a multiplikátor mértéke függ a munkaerő szerkezetétől is: a magasabb jövedelmü képzett munkaerő esetén az érték lényegesen jobb, akár kétszeres vagy magasabb lehet (Moretti 2010).

A boomtérségek dinamikusan változó pillanatnyi egyensúlyát a magasabb bérek elérhetősége szabályozza, és a bérelőnyök kimerülése vezet a visszaesési fázis megindulásához is. A fejlesztési tevékenység nagy mennyiségü, gyakran speciális képesítéssel rendelkező munkaerőt igényel, ami olyan bérkülönbségeket teremt, hogy jelentős, térségek és ágazatok közötti munkaerőmozgás megy végbe. ${ }^{5} \mathrm{Az}$ áramlás térben ideiglenes beköltözés vagy hosszú távú ingázás formá- 
jában is jelentkezhet, de természetesen áttételesen az ágazatok közötti mozgás is lehet térbeli: a szolgáltató- és más ipari ágazatokat a magasabb bérek megszerzése érdekében elhagyók egy részének helyére új betelepülők lépnek. A felhajtott bérek és a többletkereslet hatására munkaerő áramlik a boom ágazataiba és a szolgáltatásokba, új vállalkozások jelennek meg a piacon (Merrifield 1984, Haefele, Morton 2009). A vidéki, korábban gyengén fejlett és aránylag zárt gazdaságú térségekben azonban a konjunktúra a keresletnövekedésen kívül kockázatokat is jelent a helyi szolgáltatószektor számára. A többletkereslet külső, jó tőkeellátottsággal és méretgazdaságossági előnyökkel rendelkező versenytársakat vonzhat a térségbe; ez jelentős kiszorító hatást fejthet ki részben az új vállalkozások potenciális munkaerejének elszívásával, részben a piac megszerzésével. Különösen igaz ez a dekonjunkturális szakaszban, amikor a zsugorodó „torta” szeleteiért folyó verseny óhatatlanul piaci szereplők kilépéséhez/megszünéséhez vezet.

Mint Blanchard, Katz (1992), Carrington (1996), Greenstone, Moretti (2004) és Marchand (2011) hangsúlyozza, egyfajta foglalkoztatási sokk zajlik le, amelyet a bérek és a munkaerő-szükséglet módosulása vált ki. A foglalkoztatási sokkok fogalma a szakirodalomban elsősorban üzembezárásokhoz, tömeges leépítésekhez kapcsolódik. A boom esetén azonban egy bérkülönbségek által kiváltott konjunkturális és egy megszünésük utáni dekonjunkturális szakasz, egy pozitív és egy negatív sokk követi egymást. A sokk nagymértékü (a térség gazdasági aktivitásához mérten számottevő kilengés következik be), anticipált (a boomról előzetes információk állnak rendelkezésre, amelyek a térségen belüli és kívüli várakozásokat is módosítják) és ideiglenes (a konjunktúra és a dekonjunktúra ténye egyaránt előre ismert).

A multiplikatív hatásokról számos esettanulmány született. Az energetikai nagyberuházások közvetlen állásteremtő hatása rendkívül gyenge a befektetett tőkéhez mérten: Cocklin és Kelly (1992) két nagy projekt kapcsán kimutatta, hogy egy állás létrehozásának költségvonzata sokszorosan meghaladta a más ágazatokban megvalósult beruházásokét, nem lebecsülhető azonban a multiplikátorhatás; becslések szerint egyes olajipari projekteknél az új állások többszöröse jött létre kapcsolódó iparágakban és a szélesebben vett térségi gazdaságban. Glasson, van Der Wee és Barrett (1988) a somerseti Hinkley Point atomerőmű bővítése esetén szintén a közvetett foglalkoztatás szerepét hangsúlyozta: becsléseik az építés csúcsidőszakában 3500 alkalmazottra 580 és 1010 közötti, az üzemeltetési fázisban 470 alkalmazottra 100 és 190 közötti új munkahely kialakulását valószínűsítették. Marchand (2011) szerint Nyugat-Kanada energiatermelési boomjait vizsgálva az energiakitermelési szektor tíz új állására 2,8 építőipari, 2,1 kereskedelmi és 4,6 szolgáltatásokban létrejött munkahely jutott, és ezek a munkahelyek a dekonjunktúra után is viszonylag tartósaknak bizonyultak. Az olaj- és gáztermelési boom a térségi jövedelmeket 56\%-kal emelte meg: a multiplikáció mellett pozitív irányú szerkezetváltás ment végbe, bár a helyi ipar jelentősége ezen belül nem volt szignifikáns, mivel vállalatai nem tudtak kapcsolatba lépni az új ágazatokkal. Kevésbé voltak kedvezőek az USA-ban lezajlott két évtizedes 
szénbányászati boom következményei (Black, McKinnish, Sanders 2005). Itt tíz új energiatermelési állás összesen kevesebb mint két munkahelyet hozott létre az építőiparban, kereskedelemben és szolgáltatásokban; ennek pedig elsősorban a munkaerō-piaci alkalmazkodás lassabb üteme volt a kiváltó oka.

A hatások előzetes becslésére több módszer adódik. Viszonylag egyszerü, könnyen értelmezhető és aránylag kevés adatból kiszámolható képet mutatnak a statikus szemléletű (adott időpontokra kiszámított, majd a végbemenő változásokat összevetéssel azonosító) gazdaságibázis- és input-output-modellek (Rubin, Solomon 1983, Mentzas, Capros, Samouilidis 1987); a becslés talán legjobb eszközét azonban a keynesi multiplikátor továbbfejlesztett, térben és időben végbemenő folyamatokra alkalmazott változata adja. Alapértelmezésében a multiplikátormodell szintén statikus szemléletű (Lengyel, Rechnitzer 2004), a becslések általában nagyon magas aggregációs szinten, a keynesi alapmodellben nemzetgazdaságok szintjén végezhetők el, az eredmények pedig jelentős területi különbségeket takarnak (Armstrong, Darrall, Grove-White 1997). Bizonyos módszerek, így a mikroszimulációs modell, képesek a nagyon finom területi különbségek feltárására (Ballas, Clarke 1999), de alkalmazásuk előfeltétele a finom területi skálájú adatok elérhetősége, amely nem minden statisztikai rendszerben biztosított. Mivel vidéki térségekben gyakran viszonylag zárt gazdaságokról beszélhetünk, az eredeti multiplikátormodell módosított, területi szemléletű változata alkalmazható (Glasson, van Der Wee, Barrett 1988).

\section{A térségi vállalkozói rendszer fejlódése - tartós hatások}

A foglalkoztatás és gazdasági aktivitás növekedése hosszú távon a multiplikátorhatás és a központi iparágból származó átszivárgó hatások (spilloverek) mellett a térségi vállalkozói rendszer átalakulásával megy végbe. Spilling (1996a, 1996b) a Lillehammerben megrendezett 1994-es téli olimpia példáján mutatta be, hogy a központi fejlesztés új impulzusai miként képesek változásokat generálni a keresletélénkítésen, majd a vállalkozói klíma átalakításán keresztül. Értelmezésében egy „megaesemény”, amelyet pozitív foglalkoztatási sokként értelmezhetünk, különleges jelentőségü a fejlődést egyébként előrehajtó vállalkozói események körén belül, mivel méretével, jövedeleminjekciójával és újszerüségével megtöri azok sorát, és újraszervezi a gazdaság viszonyrendszereit.

A legtöbb térségi gazdaság valamilyen szinten útfüggő, vagyis a bennük meghozott döntések nem függetlenül, hanem korábbi tapasztalatok, történeti minták, fejlődési pályák hatása alatt születnek. Térgazdasági értelemben az útfüggő fejlődés hagyományok általi meghatározottságot jelent, vagyis azt, hogy egy térség még akkor sem tud letérni egy adott fejlődési pályáról, ha egyébként érdekében állna (Storper 1992, Grabher 1993). Spilling szerint a megaesemények megszakíthatják ezt az útfüggő fejlődést, és előnyeit a térségi gazdaság szereplői tanulási folyamat keretében a saját javukra fordíthatják. A rövid távon létező 
piacokon megszerzett tudás és tőke visszaforgatásával új vállalkozások, termékek, üzleti kapcsolatok, szakértelmek és szerepminták jönnek létre. Empirikus kutatásai kimutatták, hogy a hosszú távú foglalkoztatásgeneráló hatás nem volt számottevő; inkább kvalitatív, szerkezeti javulás ment végbe, részben pedig az országon belüli reallokáció, a gazdasági erőforrások átcsoportosítása volt megfigyelhető. Ezek a megállapítások összecsengenek Jasmandnek és Maenningnek (2007) az 1972-es müncheni nyári olimpiáról készült elemzése eredményeivel, bár annyiban eltérnek tőlük, hogy itt az elhanyagolható foglalkoztatási hatás mellett jelentős és tartós jövedelemnövekedés volt megfigyelhető az olimpia régiójában. Más tanulmányok hasonló eredményekre jutottak Los Angeles és Atlanta esetében.

\section{A boom hatása a közszolgáltatásokra, az infrastruktúra- ellátásra és a társadalmi problémákra}

\section{A boom által elóidézett hiányjelenségek}

A boom során tapasztalt népességnövekedés a közszolgáltatásokra, infrastrukturális ellátásra és a társadalmi problémákra is hatást gyakorol. Az árak kereslet hajtotta emelkedése megnehezítheti a helyi lakosság lakhatási feltételeit, a jövedelemkülönbségeken keresztül kiszoríthatja őket az ingatlanpiacról ${ }^{6}$ és egyes szolgáltatások élvezetéből; vagy - mint Cocklin és Kelly (1992) jelzi - a kiadó szállások lekötésével csökkentheti az idegenforgalom bevételeit is. A kisebb népességszámra méretezett infrastruktúrahálózat (víz, villany, szennyvíz, közút) és közszolgáltatások (iskolarendszer, rendőrség, tűzoltóság, egészségügy, szemétszállítás, tömegközlekedés stb.) gyakran nem képesek ellátni a magasabb népesség igényeit.

A következményeket legegyszerübben a 2. ábra segítségével szemléltethetjük: a konjunkturális szakaszban az infrastruktúra és a szolgáltatások iránti kereslet rohamos emelkedésével és a kínálati oldal lassabb, időben is lemaradó (reaktív) alkalmazkodásával kapacitáshiány lép fel, amely kezelés hiányában radikálisan ronthatja a térségben élők életminőségét. A beruházási ciklus dekonjunkturális szakaszában jelentős keresletcsökkenés megy végbe. Ez szintén problémákat okozhat: a boom időszakára tervezett infrastruktúra és szolgáltatások szintje meghaladhatja az újonnan kialakuló egyensúly keresletét; a fölösleg elviselhetetlen finanszírozási terheket róhat a fenntartó önkormányzatra.

A közszolgáltatások iránti többletkereslet, a zsúfoltság és színvonalromlás érzete valós hatás, de szubjektív elemei is kimutathatók (Merrifield 1984, Brown, Geertsen, Krannich 1989): a fokozott aktivitással több eleve létező probléma válik kritikussá vagy kerül napvilágra; a régi lakosság és az ideigle- 
2. ábra: A közszolgáltatások és infrastruktúra kereslete és kínálata közötti különbözet Mismatch between service and infrastructural demand

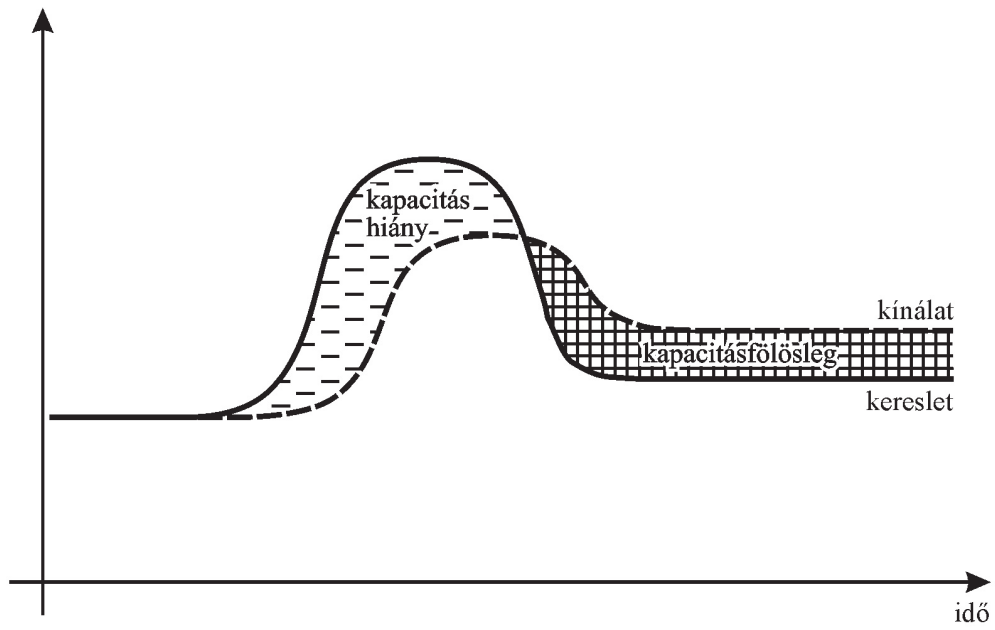

Forrás: A szerző szerkesztése.

nesen betelepülők között ellentétek alakulnak ki. Az őshonos lakosság szociális kapcsolatrendszere meggyengül, az újonnan megjelenők között pedig kialakulatlan, s gyakran enklávészerűen elkülönülnek a településen belül. Ez önmagában fokozza az anonimitás, szociális elszigeteltség érzetét, csökkenti a közösségen belüli információáramlás hatékonyságát és a közügyekben való részvételt. Így még olyan településeken is ,érzékelték” a bünözés növekedését, ahol az adatok ezt semmilyen módon nem támasztották alá (Brookshire, d'Arge 1980).

A szakirodalomban „szétziláltságként” (disruption) említett jelenség tehát egyszerre objektív és szubjektív tényezők összhatása. Korai tanulmányok csak a boom időszakában vizsgálták a jelenséget, de későbbi kutatások kimutatták, hogy a kihatások tágabb időintervallumra terjednek ki. Brown, Geertsen, Krannich (1989) és Brown, Dorius, Krannich (2005) vidéki boomtérségekben megismételt kutatásai rávilágítottak, hogy a helyi attitüdökben és társadalmi struktúrákban anticipatív módon, már a konjunktúraperiódus előtt megjelentek a boom egyes negatív társadalmi következményei; sőt, a konjunktúraciklus után is fennmaradtak. A közösségi elégedettség négy vizsgált indexéből három (a közösséggel való elégedettség, a társadalmi kapcsolatok, a helyi kötődés) csak a boom lezárulása után 9-13 évvel tért vissza kiinduló szintjére, egy (a bizalom) pedig soha. Hasonló eredményeket mutatott Brown, Hudspeth, Stone (2000) kutatása a Mercedes Benz egy alabamai nagyberuházása kapcsán: nem csupán az elégedettség egyes paraméterei, hanem az egész közösségi lét értelmezése megváltozott; csökkent a lakosság helyi kötődése és közösségi orientációja. Egyes kutatások a 15\%-os vagy magasabb növekedési rátát tartják annak a határnak, ahol a közösségi kapcsolatok és az intézményrendszer müködése súlyos károkat szenvedhetnek (Gilmore in Rubin, Solomon 1983). 


\section{A hiányjelenségek megelózése és mérséklése}

A szükségletek előzetes becslése nélkül meghozott beruházási döntések a kapacitások alul- vagy felültervezését eredményezhetik; különösen akkor, ha előzetesen az sem ismert, hogy sor kerül-e a boomot kiváltó beruházások egy részére, illetve azok milyen mértékű keresletnövekedéssel járnak. Problémát jelent a szükséges közszolgáltatások és infrastruktúra előfinanszírozása. A szükséges kapacitások egy részét előzetesen kell felépíteni, de ehhez gyakran nem állnak rendelkezésre sem megfelelő források, sem a források előteremtésére alkalmas önkormányzati eszközök (pl. adókivetési vagy kötvénykibocsátási jog) - vagy a megszerzett többletjövedelmek csak utófinanszírozást tesznek lehetővé. Mindezekkel együtt a fejlesztések finanszírozására különböző boomtérségekben az önkormányzati eszközök széles körét használták fel az előfinanszírozástól a helyi adókig (Merrifield 1984, Rubin, Solomon 1983). Magyarországon a helyi fejlesztői autonómia szűkössége és az önkormányzatok fölötti szigorodó pénzügyi kontroll miatt azonban túlnyomó többségük nem alkalmazható (a helyi fejlesztés eszközeiről és korlátairól lásd Mezei 2006, 2008 és Hervainé Szabó 2008, az önkormányzatok pénzügyi kontrolljáról Pálné 2010).

A közszolgáltatások és az infrastruktúra optimális szintje a konjunkturális fázisban jelentkező hiány szociális, és a dekonjunktúrában fennmaradó felesleg fenntartási költségeinek minimalizálásával határozható meg. Ezt a problémát nem lehet teljesen megszüntetni: vagy az egyik, vagy a másik oldalon költségek keletkeznek, méghozzá, ha nem a beruházó vagy alvállalkozói által felépített, üzemeltetett majd lebontott kapacitásokról (például konténervárosokról) van szó, akkor az érintett települések oldalán. Különösen égetően jelentkezik a probléma, ha a boom előnyei és hátrányai nem ugyanazon a településen összpontosulnak; az elsőt pozitív, a másodikat negatív externáliaként érzik meg egy térség települései (Merrifield 1984, Leistritz, Murdock 1987). Amennyiben a jogszabályok lehetővé teszik, az adópolitika módosítása (forgalmi adók bevezetése) vagy egy az érintett területet magában foglaló speciális körzet kialakítása jelenthet megoldást.

Hagyományosan a gazdasági szereplők a kapacitásbővítés, az érintett települések a szociális és fenntartási költségek alacsonyan tartásában érdekeltek; ez az érdekellentét azonban előzetes, anticipatív tervezéssel és participatív, az érintetteket bevonó döntéshozatallal jelentősen mérsékelhető. Az ideiglenes beruházások egy része lebontható és helye rekultiválható vagy alternatív hasznosításba vonható (például közművesített ipari területként), mások azonban hosszú távon meghatározzák a település szolgáltató- és infrastrukturális kínálatát. A tartós beruházások szintje a boom utáni egyensúly figyelembevételével dönthető el: ezt részben az előrejelzett tartós népességnövekedés, részben a település térségi funkciója befolyásolja - egyes közszolgáltatások (például a kórházak) bővítése és modernizációja évtizedekig javítja az életminőséget a beruházás vonzáskörzetében, míg az infrastruktúra és a közművek a városrendezés szolgálatába állíthatók. 
Az optimális beruházási szint meghatározására Cummings és Schulze (1978) közölt egy ma is használható modellt. Megállapítják, hogy az elméletileg optimális beruházási szint ott található, ahol a boom utáni többletkapacitásban lekötött tőke határköltsége megegyezik a kapacitáshiány okozta alacsonyabb szolgáltatási és infrastrukturális színvonal szociális határköltségével. A beruházási és társadalmi költségeket azonban nemcsak a létrehozott kapacitások mennyisége, hanem a megvalósításban érvényesülő időtényező is nagyban befolyásolja (375.): „az építési fázis alatt mind a népességnövekedésben, mind a munkaerő állományában annál nagyobb stabilitás mutatható ki, minél alacsonyabbak a kamatlábak, és minél hamarabb megvalósulnak az infrastrukturális beruházások. Ha a szociális infrastruktúra-beruházások csak az építési fázis során indulnak el, bizonyíthatóan erősödik a boomhatás, amely az instabilitás mérséklődése helyett annak növekedésével jár együtt." Vagyis tradeoff-kapcsolat érvényesül a boomtérség bérei és egy före jutó szociális infrastruktúrája között: a rossz infrastruktúrát jobb bérekkel kell kompenzálni, s ellenkezőleg, fejlesztésével bérmegtakarítások érhetők el.

\section{A Magyarországon megvalósuló nagyberuházások kérdései}

Magyarországon a jelentős agglomerációkon kívül eső, kis- és középvárosi környezetben megvalósított ipartelepítési és létesítménybővítési nagyberuházások mind a boomtérségek, mind a magyar gazdasági és területi fejlődés speciális problémáit felvetik: az eltérő társadalmi és gazdasági környezetben a kedvező és kedvezőtlen hatások is másként jelennek meg.

Fennálló szociokulturális eltérés, hogy az empirikusan vizsgált boomok többsége a Magyarországnál sokkal mobilabb munkaerővel és jobb tőkefinanszírozási feltételekkel rendelkező Észak-Amerikában zajlott le, és ezt a feltételezést az irodalomban megjelent empirikus vizsgálatok is tükrözik. Nálunk nehézkesebbek a migráció mechanizmusai, fejletlenebb a vállalkozói rendszer, és (különösen vidéki térségekben) sokkal körülményesebb vállalkozói hitelekhez jutni, ami alapján gyengébb multiplikátorhatás érvényesülését feltételezhetjük.

Elmaradnak vagy csökkennek a lehetséges tartós előnyök, ha a boom által vonzott, jó pénz-, tudás- és kapcsolati tőkével rendelkező külső (főként fövárosi vagy külföldi) versenytársak elszívják a boom előnyeit, elsősorban a különösen jövedelmező szerződéseket, és csak a potenciális előnyök töredéke realizálódik a beruházás környezetében. A beruházásokat küldő és befogadó gazdaság környezeti (technológiai, tőkeellátottsági, akár kulturális) fejlettségi különbségei is hasonló problémákat idézhetnek elö, bár ezek a relatív eltérések nemcsak Magyarországon, hanem a centrumtérségek és a perifériák között máshol is jelentkeznek. Inkább egy abszolút társadalmi és gazdasági 
fejlettségi küszöböt feltételezhetünk, amely alatt a helyi gazdaság már nem képes megkötni és tartósan a maga javára fordítani a megjelenő többleterőforrásokat (avagy multiplikálnánk, de nincs mit). A boommal foglalkozó szerzők közül sokan hangsúlyozták az elszivárgás problémáját, és Magyarország alultőkésedett, fragmentált vállalkozói szektora esetén a veszély jelentős - még akkor is, ha a beruházó maga kínál egyfajta „terített asztalt”. Aktív vállalati és fejlesztői szerepvállalás szükséges, amennyiben cél, hogy a keletkező hosszú távú gazdasági előnyök egy része a térség gazdaságában realizálódjon.

A hazai ipari nagyberuházások elsősorban az alapvető feladatokat ellátó fizikai alkalmazottak és a technológiát adó ország szakemberei körében járnak ideiglenes letelepedéssel. Ahogy a kecskeméti Mercedes-beruházás példája is mutatja, a létesítménytervező tevékenység jelentős része a fővárosban zajlik, és csak alkalmi ingázásra kerül sor, amelynek már csekélyebb közvetett gazdasági hatása van a térségben. Valamilyen mértékben bekövetkezik a beruházás környezetében és a szomszédos térségekben található munkaerő mobilizációja és ingázási aktivitásának felerősödése (különösen egyes építőipari vállalatoknál), de az eleve alacsony fejlettségi szint, a mobilizálható tartalékok csekélysége és az alacsony munkaerö-mobilitás ezt behatárolja. A beruházáshoz kapcsolódó speciális, tudás- és technológiaigényes feladatok esetében még kisebb hatással kell számolnunk - a legtöbb magyar kis- és középváros tágabb környezetében sem találunk bekapcsolódni képes tervező- és kivitelezővállalatokat. A meghatározó tényezőt tehát az építkezés területén tartósan jelen lévők adják, és döntően az ő fogyasztásuk adja azt a jövedeleminjekciót, amelynek hatásai a multiplikátorhatáson keresztül megjelennek a térség gazdaságában.

Ez a tanulmány nem vállalkozhatott a hazai boomfolyamatok és a velük járó összetett konjunkturális hatások részletes vizsgálatára, illetve terjedelmi okokból nem tért ki a boom hatásainak előrebecslésére szolgáló (az eredeti kutatás zárótanulmányában bőségesebben tárgyalt) módszerek részletes ismertetésére sem. Célja egy jelentős, a modern magyar regionális tudományban kevés figyelmet nyert kérdéskör elméleti alapjainak bemutatása, figyelemfelhívás volt. A specifikus nagyberuházások keltette hatások alaposabb megismerése empirikus, esettanulmányokra és azok szintézisére törekvő kutatásokat igényel, s ezek a kutatások akár a városi térségek fejlődése, akár az újraiparosítás és a befektetésvonzásra irányuló fejlesztési politikák kérdésköre kapcsán a területi folyamatok alaposabb megismerésével, a területi politikák megalapozottságának erősödésével kecsegtetnek.

\section{Köszönetnyilvánítás}

A tanulmány alapjául szolgáló munka a Paksi Atomerőmű Zrt. által támogatott kutatás keretében valósult meg. A szerző köszönettel tartozik anonim lektorainak, akik javaslataikkal és kritikáikkal hozzájárultak a tanulmány továbbfejlesztéséhez. A fennmaradó hibákért a szerzőt terheli a felelősség. 


\section{Jegyzetek}

1 Így a területfejlesztésnek az ipari beruházások kapcsán kialakult problémáiról és a mérséklésükre alkalmazott eszközrendszer fejlődéséről lásd Tatai (1973) áttekintését; az infrastrukturális ellátottságról és infrastruktúra-fejlesztésről Kőszegfalvi (1975) írását; a településhálózat-fejlesztés és az iparfejlesztés kapcsolatainak egy konkrét példájaként Fodor (1980) cikkét a kiemelt alsófokú központok helyzetéről és iparfogadási készségéről; a területi tervezés beruházási döntésekben játszott szerepéről Tóth (1977), az urbanizációs problémákról Perczel (1978), Kőszegfalvi (1979) és Zala, Fodor (1979) cikkeit.

2 A szubnacionális elemző- és stratégiai tervezési kapacitások hiányosságainak problémájáról lásd Sucháček (2008) és Suvák (2010) megállapításait.

3 Így Black, McKinnish, Sanders (2005) a két évtizedes amerikai szénbányászati boom konjunkturális szakaszában 1,174-es, dekonjunkturális szakaszában 1,349-es multiplikátort tárt fel; a ciklus aszimmetrikusan zajlott le. Figyelemre méltó még, hogy a dekonjunktúra erősebben érintette a foglalkoztatást, mint a béreket; utóbbiak nem süllyedtek vissza a boom előtti időszak szintjére.

4 A külső erőforrások térségbe integrálásáról és a belső erőforrások mobilizálásáról lásd Bajmócy (2011) megállapításait.

5 A mobilitás a lokális munkaerőpiac viszonyait is átrendezheti, egyes ágazatok foglalkoztatása kirívó esetekben akár 30-40\%-kal is csökkenhet, hiányszakmák alakulhatnak ki. A kisipari tevékenységekben ilyen jelenségek tapasztalhatók pl. a kecskeméti Mercedes-üzem környezetében; a felszabadult állásokat még nem töltötték be térségen kívülről érkező munkavállalók.

6 A Kecskemét környéki lakáspiacon a Mercedes-beruházás a bérleti díjak 30-50\%-os emelkedését hozta (A Mercedes 160\%-on... 2011).

\section{Irodalom}

Armstrong, H. W., Darrall, J., Grove-White, R. (1997): The local economic impact of construction projects in a small and relatively self-contained economy: The case of Lancaster University. Local Economy 2, 146-159.

Bajmócy Z. (2011): Bevezetés a helyi gazdaságfejlesztésbe. JATEPress, Szeged

Ballas, D., Clarke, G. (1999): Regional versus local multipliers of economic change? A microsimulation approach. Paper presented at the 39th European Regional Science Association (ERSA) Congress, University College, Dublin

Black, D., McKinnish, T., Sanders, S. (2005): The economic impact of the coal boom and bust. The Economic Journal, 115. 449-476.

Blanchard, O. J., Katz, L. F. (1992): Regional evolutions. Brooking Papers on Economic Activity, 1, 1-76.

Brookshire, D. S., d'Arge, R. C. (1980): Adjustment issues of impacted communities, or, are boomtowns bad? Natural Resources Journal, 3, 523-546.

Brown, R. B., Dorius, S. F., Krannich, R. S. (2005): The boom-bust-recovery cycle: Dynamics of change in community satisfaction and social integration in Delta, Utah. Rural Sociology, 1, 28-49.

Brown, R. B., Geertsen, H. R., Krannich, R. S. (1989): Community satisfaction and social integration in a boomtown: A longitudinal analysis. Rural Sociology, 4, 568-586.

Brown, R. B., Hudspeth, C. D., Stone, C. L. (2000): Social impacts of large scale economic development projects in the rural South: A longitudinal re-study of Vance, Alabama and the impacts of Mercedes Benz. TVA Rural Studies Contractor Paper, 00-09.

Carrington, W. J. (1996): The Alaskan labor market during the pipeline era. Journal of Political Economy, 1, 186-198. 
Cocklin, C., Kelly, B. (1992): Large-scale energy projects in New Zealand: Whither social impact assessment? Geoforum, 1, 41-60.

Cummings, R. G., Schulze, W. D. (1978): Optimal investment strategy for boomtowns: A theoretical analysis. American Economic Review, 3, 374-385.

Fodor M. (1980): Kiemelt alsófokú központok várható ipari fejlesztése. Területi Statisztika, 2., 108-119.

Glasson, J., van Der Wee, D., Barrett, B. (1988): A local income and employment multiplier analysis of a proposed nuclear power station at Hinkley Point in Somerset. Urban Studies, 25, 248-261.

Grabher, G. (1993): The weakness of strong ties. The lock-in of regional development in the Ruhr area. In: Grabher, G. (ed.): The embedded firm. On the socioeconomics of industrial networks. Routledge, London, 255-277.

Greenstone, M., Moretti, E. (2004): Bidding for industrial plants: Does winning a 'million dollar plant' increase welfare? National Bureau of Economic Research, Cambridge MA

Haefele, M., Morton, P. (2009): The influence of the pace and scale of energy development on communities: Lessons from the natural gas drilling boom in the Rocky Mountains. Western Economic Forum, 3, 1-13.

Hervainé Szabó Gy. (2008): Az integratív várospolitika tapasztalatai a hazai várostérségekben. Tér és Társadalom, 1., 77-91.

Jasmand, S., Maenning, W. (2007): Regional income and employment effects of the 1972 Olympic Summer Games. IASE/NAASE Working Paper Series, 07-12.

Kóródi J., Kőszegfalvi Gy. (1971): Városfejlesztés Magyarországon. Kossuth Könyvkiadó, Budapest

Kóródi J., Márton G. (1968): A magyar ipar területi kérdései. Kossuth Könyvkiadó, Budapest

Kőszegfalvi Gy. (1975): Városaink infrastrukturális ellátottsági viszonyainak színvonala és a fejlesztés néhány problémája. Területi Statisztika, 3., 263-275.

Kőszegfalvi Gy. (1978): A korszerü ipartelepítés alapjai. Műszaki Könyvkiadó, Budapest

Kőszegfalvi Gy. (1979): A magyarországi városhálózat helyzete, fejlődésének problémái, ellentmondásai, a fejlesztés feladatai. Területi Statisztika, 2., 121-130.

Leistritz, L. F., Murdock, S. H. (1987): Local fiscal impacts of large-scale projects: Use of impact models as planning and policy analysis tools. Socio-Economic Planning Sciences, 1., 9-17.

Lengyel I., Rechnitzer J. (2004): Regionális gazdaságtan. Dialóg Campus Kiadó, Budapest-Pécs

Marchand, J. (2011): Local labor market impacts of energy boom-bust-boom in Western Canada. University of Alberta Department of Economics, Edmonton

Mentzas, G. N., Capros, P., Samouilidis, I. E. (1987): Modelling the regional economic impacts of energy development: A survey. Socio-Economic Planning Sciences 3., 151-158.

A Mercedes 160\%-on pörgeti Kecskemét lakáspiacát. http://penzcentrum.hu/cikk/1026372/1/a_ mercedes_160-on_porgeti_kecskemet_lakaspiacat (2010. XII. 21)

Mezei C. (2006): Helyi gazdaságfejlesztés Közép-Kelet-Európában. Tér és Társadalom, 3., 95-108.

Mezei, C. (2008): The Role of Hungarian Local Governments in Local Economic Development. Discussion Papers, 63. Centre for Regional Studies of Hungarian Academy of Sciences, Pécs

Moretti, E. (2010): Local multipliers. American Economic Review, 2., 1-7.

Németh N. (2009): Fejlödési tengelyek az új térszerkezetben. ELTE Regionális Tudományi Tanszék, Budapest, (Regionális Tudományi Tanulmányok; 15.)

Pálné Kovács I. (2010): Meggondolások az önkormányzatok pénzügyi helyzetéről folyó vitákhoz. Pénzügyi Szemle, 3., 500-504.

Perczel Gy. (1978): Főbb társadalmi céljaink és az urbanizáció. Területi Statisztika, 6., 613-621.

Rubin, B. M., Solomon, B. D. (1983): Economic and fiscal impact analysis of energy development projects: Coal liquefaction in the Illinois basin. Socio-Economic Planning Sciences, 1., 11-20.

Spilling, O. R. (1996a):Mega-event as a strategy for regional development: The case of the 1994 Lillehammer Winter Olympics. Entrepreneurship and Regional Development, 8., 321-343.

Spilling, O. R. (1996b): The entrepreneurial system: On entrepreneurship in the context of a megaevent. Journal of Business Research, 36., 91-103.

Storper, M. (1992): The limits to globalization: Technology districts and international trade. Economic Geography, 1., 60-93. 
Sucháček, J. (2008): Territorial Development Reconsidered. VŠB - Technical University of Ostrava Faculty of Economics, Ostrava. http://mpra.ub.uni-muenchen.de/15009/ (2011. X. 05.)

Suvák A. (2010): Integrated urban development strategies - Comparison of European and Hungarian approaches. Journal of Landscape Studies, 3., 139-146.

Tatai Z. (1973): A területfejlesztési politika célja és eszközrendszere az iparban. Területi Statisztika 5., 518-531.

Tóth L. (1977): A területi tervezés helye, szerepe a népgazdasági és a tanácsi tervezés rendszerében. Területi Statisztika, 6., 621-630.

Varjú V. (2009): A területi tervezés legújabb környezetértékelési metódusa - A stratégiai környezeti vizsgálat integrációja a döntéshozásba. Tér és Társadalom, 1., 55-65.

Zala Gy., Fodor L. (1979): Városaink fejlesztésének gazdasági hatótényezői. Területi Statisztika, 4., 391-398. 